\title{
Czy w operacyjnym raku przełyku należy stosować indukcyjną chemioradioterapię? Jednoczasowa CRT: T1 b N+, T2-4a N0-N+
}

\author{
Grzegorz Wallner
}

Leczenie nowotworów pochodzenia nabłonkowego w przełyku stale wzbudza kontrowersje. Rak przełyku, niezależnie od tego, czy jest to rak płaskonabłonkowy czy coraz częściej występujący gruczolakorak przełyku (oba typy zaliczane są do tych nowotworów złośliwych układu pokarmowego, które wiążą się ze stosunkowo wysokim odsetkiem niepowodzenia), są niewdzięczne zarówno do leczenia chirurgicznego, jak też przy licznych próbach leczenia skojarzonego. Mimo systematycznego rozwoju wiedzy, interdyscyplinarnego leczenia raka przełyku, nowych technik diagnostycznych, postępu technologicznego chirurgicznych technik minimalnie inwazyjnych i zdecydowanie lepszych umiejętności w opiece pooperacyjnej wyniki terapii raka przełyku stale pozostają na niezadowalającym poziomie. W warunkach polskich jedynie 10\%-15\% raków przełyku pierwotnie kwalifikuje się do chirurgicznego leczenia radykalnego. Nadzieję na poprawę niekorzystnych wyników odległych w terapii raka przełyku upatruje się albo w diagnostyce wczesnych raków, pozwalających na zastosowanie metod endoskopowych (EMR, SMD), albo raków w stopniu zaawansowania kwalifikujących się do radykalnego wycięcia przełyku (MIE - technikami minimalnie inwazyjnymi, ezofagektomii konwencjonalnej THE/TTE), albo w kompleksowym leczeniu skojarzonym, łączącym zabieg chirurgiczny i dostępne metody leczenia skojarzonego (chemioterapii i/lub radioterapii ChT/ChRT).

Od lat toczą się debaty odnośnie wartości leczenia skojarzonego raka przełyku. Prezentowane wyniki często były sprzeczne, niejednoznaczne, krytykowane za dużą heterogenność analizowanych przypadków klinicznych i metod terapii oraz brak poprawności metodologicznej. Na podstawie danych z literatury dysponujemy zróżnicowanymi danymi, począwszy od wczesnych publikacji weryfikujących retrospektywnie wyniki leczenia operacyjnego, chemioterapii, radioterapii jako metod niezależnych — poprzez kojarzenie powyższych metod, wprowadzanie wariantów kompleksowej terapii przed — a ostatnio okołooperacyjnego leczenia skojarzonego — do terapii indywidualizowanej, podejścia interdyscyplinarnego, czy wreszcie terapii celowanej raka przełyku.

Zmieniły się również kryteria metodologiczne analiz klinicznych. Zgodnie z zasadami evidence base medicine - EBM aktualnie najwyższy poziom i stopień rekomendacji mają prospektywne doniesienia wieloośrodkowe z randomizowanym, losowym doborem pacjentów do weryfikowanych wariantów terapii - pRCT, ale przede wszystkim metaanalizy powyższych publikacji oraz analizy statystyczne z dużych baz danych populacyjnych.

Zgodnie z zaleceniami towarzystw naukowych i organizacji zajmujących się opracowywaniem wytycznych najbardziej optymalnym postępowaniem terapeutycznym w zaawansowanym raku przełyku jest leczenie skojarzone, z przedoperacyjną, neoadiuwantową/indukcyjną ChRT, z następowym zabiegiem chirurgicznym wycięcia przełyku. Tylko w ostatnich kilkunastu latach XXI wieku ukazało się kilkanaście metaanaliz skojarzonego leczenia raka przełyku. Mimo jakościowej poprawy metodologicznej cytowanych publikacji wyniki leczenia raka przełyku nadal są niejednoznaczne, a wartość proponowanych strategii terapeutycznych jest dosyć często kwestionowana.

\section{Should inductive chemo-radiotherapy be used in locally advanced oesophageal cancer} in $\mathrm{T} 1 \mathrm{~b} \mathbf{N}+, \mathrm{T} 2-4 \mathrm{a} \mathbf{N}-\mathrm{N}+$ stages?

The therapy of oesophageal tumours of epithelial origin still arouses controversy. Oesophageal cancers, regardless of whether squamous cell carcinoma, or which currently more often occurs, adenocarcinoma, both types are among the 
most malignant tumours of the digestive tract. Their incidence is associated with a relatively high rate of failure. They are both difficult to treat with surgery, and also with several attempts of combined therapy consisting radiotherapy and chemotherapy (RT/ChT).

Despite the systematic development of knowledge, attempts of individualisation and interdisciplinary treatment of oesophageal cancers, new diagnostic techniques, technological progress of minimally invasive surgical techniques, and far better skills in post-operative care, the results of oesophageal cancer therapy permanently remain at an unsatisfactory level. In Poland, only 10-15\% of cancers of the oesophagus are originally eligible for radical surgical excision. The hope to improve unfavourable long-term results in the treatment of oesophageal cancer is believed to be either in the diagnosis of early cancers, allowing the use of endoscopic methods (endoscopic mucosal resection - EMR, submucosal dissection - SMD), or cancers in a stage qualifying them for radical excision of the oesophagus (minimally invasive oesophagectomy - MIE, with open approach transhiatal or transthoracic oesophagectomy - THE/TTE), or in complex therapy of surgery and available combinations of RT with ChT.

For years there has been a debate about the value of combined therapy in oesophageal cancer. The published data are often contradictory, ambiguous, criticised for large heterogenity of the clinical cases analysed and therapeutic approaches, as well as for the lack of methodological correctness. In the literature we can find the data from early publications retrospectively verifying the results of surgery, chemotherapy, and radiotherapy as independent methods, and by combining these methods. We now have the introduction of different variants of complex therapy preoperatively, and recently also perioperative radiochemotherapy (RChT), the individualisation and interdisciplinary approaches, and finally attempts of targeted therapy of oesophageal cancer. There are also changes in methodological criteria for clinical analyses. In accordance with the evidence base medicine rules currently the highest level and degree of recommendations are based on multicentre studies, prospective randomised trials (MPRCT), and also meta-analyses of mPRCT or data from large/national population databases. In line with the recommendations of scientific societies, and organisations involved in developing practical guidelines, the optimal strategy for oesophageal cancer treatment is preoperative RChT in a neoadjuvant manner followed by surgical excision of the oesophagus with two or three-field lymph nodes dissection. However, despite the qualitative improvement of methodology in cited publications, the results of oesophageal cancer therapy are still poor, and the value of the proposed therapeutic strategies is quite often questionable.

NOWOTWORY J Oncol 2016; 66, 2: 167-173

Słowa kluczowe: rak przełyku, leczenie skojarzone, heterogenna ewidencja odległych wyników terapii raka przełyku Key wards: esophageal cancer, combined treatment, long-term results heterogenity

Leczenie nowotworów pochodzenia nabłonkowego przełyku stale wzbudza kontrowersje. Rak przełyku, niezależnie od tego, czy jest to rak płaskonabłonkowy czy coraz częściej występujący gruczolakorak przełyku (oba typy zaliczane są do tych nowotworów złośliwych układu pokarmowego, które wiążą się ze stosunkowo wysokim odsetkiem niepowodzenia), są niewdzięczne zarówno do leczenia chirurgicznego, jak też przy licznych próbach leczenia skojarzonego.

Mimo systematycznego rozwoju wiedzy, interdyscyplinarnego leczenia raka przełyku, nowych technik diagnostycznych, postępu technologicznego chirurgicznych technik minimalnie inwazyjnych i zdecydowanie lepszych umiejętności w opiece pooperacyjnej wyniki terapii raka przełyku stale pozostają na niezadowalającym poziomie. W warunkach polskich jedynie 10\%-15\% raków przełyku pierwotnie kwalifikuje się do chirurgicznego leczenia radykalnego. Nadzieję na poprawę niekorzystnych wyników odległych w terapii upatruje się albo w diagnostyce wczesnych raków, pozwala- jących na zastosowanie metod endoskopowych (EMR, SMD), albo raków w stopniu zaawansowania kwalifikujących się do radykalnego wycięcia przełyku (MIE — technikami minimalnie inwazyjnymi, ezofagektomii konwencjonalnej THE/TTE), albo w kompleksowym leczeniu skojarzonym, łączącym zabieg chirurgiczny i dostępne metody leczenia skojarzonego (chemioterapii i/lub radioterapii ChT/ChRT).

Od lat toczą się debaty odnośnie wartości leczenia skojarzonego raka przełyku. Prezentowane wyniki często były sprzeczne, niejednoznaczne, krytykowane za dużą heterogenność analizowanych przypadków klinicznych i metod terapii oraz brak poprawności metodologicznej. Począwszy od wczesnych publikacji weryfikujących retrospektywnie wyniki leczenia operacyjnego, chemioterapii, radioterapii jako metod niezależnych — poprzez kojarzenie powyższych metod, wprowadzanie wariantów kompleksowej terapii przed - a ostatnio okołooperacyjnego leczenia skojarzonego - do terapii indywidualizowanej, podejścia interdyscyplinarnego, czy wreszcie terapii celowanej raka przełyku. 
Zmieniły się również kryteria metodologiczne analiz klinicznych. Zgodnie z zasadami evidence base medicine - EBM aktualnie najwyższy poziom i stopień rekomendacji mają prospektywne doniesienia wieloośrodkowe $z$ randomizowanym, losowym doborem pacjentów do weryfikowanych wariantów terapii - pRCT, ale przede wszystkim metaanalizy powyższych publikacji oraz analizy statystyczne z dużych baz danych populacyjnych.

Zgodnie z zaleceniami towarzystw naukowych i organizacji zajmujących się opracowywaniem wytycznych najbardziej optymalnym postępowaniem terapeutycznym w zaawansowanym raku przełyku jest leczenie skojarzone, z przedoperacyjną, neoadiuwantową/indukcyjną ChRT, z następowym zabiegiem chirurgicznym wycięcia przełyku. Tylko w ostatnich kilkunastu latach XXI wieku ukazało się kilkanaście metaanaliz skojarzonego leczenia raka przełyku [1-13]. Mimo jakościowej poprawy metodologicznej cytowanych publikacji, wyniki leczenia raka przełyku nadal są niejednoznaczne, a wartość proponowanych strategii terapeutycznych jest dosyć często kwestionowana [14].

W często cytowanej publikacji Urschela i wsp. z metaanalizy 9 badań RCT - 1116 chorych na raka przełyku - w grupie chorych poddanych ChRT z resekcją przełyku, w porównaniu z poddanymi wyłącznie zabiegowi operacyjnemu, stwierdzono istotnie niższy odsetek zabiegów resekcyjnych przy jednocześnie wyższym odsetku operacji typu R0 ( $p=0,007$ ). Poprawa resekcyjności mikroskopowo radykalnej typu R0 wiązała się jednak z 1,72 razy wyższym ryzykiem zgonów pooperacyjnych i 1,63 razy wyższym odsetkiem powikłań [1]. Natomiast Burnmeister i wsp. (III faza badań AGITG iTROG), porównując podobne schematy leczenia w dwóch grupach liczących po 128 pacjentów, nie wykazali jakichkolwiek różnic przeżyć wolnych od wznowy czy przeżyć całkowitych w grupie chorych na raka przełyku poddanych ChRT i resekcji w porównaniu z wyłącznym leczeniem chirurgicznym [15].

Z kolei Mariette i wsp., na podstawie metaanalizy 25 badań klinicznych RCT: 5 z radioterapią RT -1120 pacjentów, 11 badań ChT - 1600 pacjentów i 9 badań ChRT - 1200 chorych na raka przełyku stwierdzili, że odsetek patologicznych, całkowitych odpowiedzi na różne warianty leczenia skojarzonego jest zmienny i zależny od dawek promieniowania i stosowanych leków (10\%-42\% pCR), z wydłużeniem życia w dwuletnich obserwacjach o 13\%$-19 \%$ [4]. Autorzy tej metaanalizy sami kwestionują wartość uzyskanych wyników, stwierdzając, że brak jest badań RCT o wystarczającej sile statystycznej, które jednoznacznie potwierdziłyby efektywność stosowanych wariantów terapii.

Podobne wyniki poprawy dwuletnich przeżyć potwierdzili Gebski i wsp. w oparciu o metaanalizę 10 badań RCT: 10 ChRT - 1209 pacjentów i 8 ChT - 1724 chorych na raka przełyku [5]. Dla chorych poddanych ChRT uzyskano wydłużenie 2-letnich przeżyć u 13\% pacjentów, natomiast w grupie ChT — jedynie u 7\%.

D'Journo i wsp. zauważają, że w okresie ostatnich 20 lat mimo intensywnych prac badawczych i stosowania równych schematów leczenia skojarzonego 5-letnie przeżycia chorych na raka przełyku pozostają bez zmian i wahają się na poziomie 15\%-34\% [13].

Sjoquist i Gebski, na podstawie metaanalizy 23 badań z randomizacją, obejmujących łącznie 4188 chorych na raka przełyku, u których zastosowano różne warianty terapii neoadiuwantowej skojarzonej: 12 RCT z ChRT - 1854 pacjentów, 9 RCT z ChT - 1981 pacjentów oraz 2 RCT ChT vs ChRT - 194 pacjentów, stwierdzili, że nadal brak jest optymalnego wariantu leczenia skojarzonego [16].

Porównując dane z 2007 roku z opublikowanymi w 2011 r., zauważyli niepokojący trend zmniejszenia odsetka dwuletnich przeżyć z 13,0\% w 2007 roku do jedynie $8,7 \%$ na podstawie metaanalizy z 2011 roku [16]. Mimo że zastosowanie przedoperacyjnej ChRT nadal pozostawało istotnie korzystne ( $p=0,0001)$, w rzeczywistości oznaczało to praktyczne korzyści dla 1 na 11 pacjentów poddanych reżimowi skojarzonego leczenia przedoperacyjnej ChRT z leczeniem chirurgicznym w stosunku do chorych poddanych wyłącznie leczeniu operacyjnemu. Co więcej, grupa pacjentów przedoperacyjnej ChRT charakteryzowała się wyższym odsetkiem zgonów pooperacyjnych i zgonów 30-dniowych. Obserwacje te były niezależne od typu raka płaskonabłonkowego czy gruczolakoraka przełyku.

Jeszcze mniej zachęcające wyniki zaobserwowano u pacjentów poddanych przedoperacyjnej ChT. Nadal dla całej grupy chorych na raka przełyku zastosowanie ChT przyniosło istotne obniżenie dwuletnich przeżyć do 5,1\% (7,0\% w metaanalizie z 2007 roku), przy $p=0,007$. Trend uzyskiwanych korzyści z przedoperacyjnej ChT był jeszcze mniej zachęcający, bo jedynie 1 na 19 pacjentów uzyskiwał poprawę przeżycia. Szczegółowa analiza danych chorych na raka płaskonabłonkowego i gruczolakoraka przełyku wykazała uzasadnienie kliniczne do przedoperacyjnej ChT jedynie w grupie chorych na raka gruczołowego przełyku $(p=0,01)$, przy braku korzyści w raku płaskonabłonkowym $(p=0,18)$. Podobnie jak u pacjentów poddanych ChRT, również w grupie ChT zaobserwowano wyższy odsetek zgonów pooperacyjnych i zgonów 30-dniowych u chorych poddanych leczeniu skojarzonemu.

Autorzy dokonali również metaanalizy porównawczej wyników leczenia skojarzonego ChRT w stosunku do ChT. Bez względu na typ histopatologiczny raka przełyku wykazano jedynie umiarkowaną, nieistotną statystycznie korzyść z zastosowania ChRT, przy $\mathrm{p}=0,07$. Jednocześnie w oparciu o wyniki przeprowadzonej metaanalizy autorzy nie potwierdzili efektywności leczenia raka przełyku przy stosowaniu sekwencyjnej chemioradioterapii. 
Z kolei grupa badaczy niemieckich z Kranzfelderem na czele dokonała przeglądu 20 publikacji wyłącznie RCT pod kątem wartości neoadiuwantowej, przedoperacyjnej ChRT bądź ChT w porównaniu z definitywnym leczeniem skojarzonym — dChRT [17]. Do metaanalizy włączono 1099 pacjentów z przedoperacyjną ChRT - 9 RCT (6 badań, rak płaskonabłonkowy oraz 3 badania, rak gruczołowy), 1707 pacjentów z przedoperacyjną ChT - 8 RCT oraz 512 chorych na raka przełyku - 3 RCT (definitywna ChRT vs leczenie chirurgiczne lub definitywna ChRT vs neoadiuwantowa ChRT z leczeniem chirurgicznym).

Podobnie jak w metaanalizie Sjoquista i Gebskiego, w badaniach Kranzfeldera i wsp. wyniki nie były jednoznaczne.W grupie przedoperacyjnej ChRT, przy poziomie całkowitych, patologicznych odpowiedzi pCR $11 \%-43 \%$, uzyskano istotną statystycznie poprawę przeżyć $(p=0,008)$ w porównaniu z leczonymi wyłącznie operacyjnie. Zastosowanie przedoperacyjnej, neoadiuwantowej ChRT okupione było jednak wyższym odsetkiem 30-dniowych zgonów w porównaniu z leczonymi wyłącznie operacyjnie $(p=0,118)$.

Natomiast Kranzfeledri wsp. zdecydowanie kwestionują wartość przedoperacyjnej ChT, która nie poprawia przeżyć ( $p=0,368$ ), nie zwiększa istotnie odsetka patologicznych, całkowitych odpowiedzi pCR (jedynie o 3\%-5\%, p =0,638). Również dane porównujące wartość neoadiuwanowej, przedoperacyjnej ChRT z leczeniem definitywnym (dChRT) są mało zachęcające. Potencjalne korzyści z przedoperacyjnej ChRT są niwelowane wyższymi odsetkami powikłań ogółem, płucnych oraz obarczone zgonami pooperacyjnymi. Jednocześnie po roku obserwacji autorzy wykazali brak różnic w zakresie przeżyć całkowitych, przeżyć wolnych od wznowy raka, a także brak różnic w wynikach dla chorych na raka płaskonabłonkowego i raka gruczołowego przełyku. Dane te są zbieżne z wcześniejszą metaanalizą Urschela i wsp. z 2003 roku [1].

Dość duże nadzieje są wiązane z obserwowanym w ostatnich latach trendem okołooperacyjnej ChRT/ChT. Szczególnie intersujące są dane dla raka gruczołowego przełyku, połączenia przełykowo-żołądkowego i raka żołądka. Ronellenfitsch i wsp., w oparciu o analizę bazy Cochrane oraz metaanalizę 8 badań RCT obejmujących dane 1049 pacjentów, stwierdzili, że największe korzyści w postaci poprawy przeżyćz ChRT/ChT okołooperacyjnej odnoszą pacjenci z gruczolakorakiem połączenia przełykowo-żołądkowego $(p=0,00022)$, pośrednią $z$ rakiem gruczołowym przełyku $(p=0,14)$, a najmniejsze chorzy na raka żołądka $(p=0,31)[18,19]$.

Istnieją różnice populacyjne występowania raka płaskonabłonkowego i gruczołowego przełyku pomiędzy mieszkańcami Dalekiego Wschodu i tzw. Świata Zachodniego. Stosowane są odmienne strategie terapeutyczne, różne schematy lekowe, z różnymi dawkami leków i różną całkowitą dawką napromieniowania, co w zasadniczy sposób utrudnia wypracowanie optymalnego wariantu terapii.
Dominuje ChRT łącznie z leczeniem chirurgicznym lub ChT z leczeniem chirurgicznym.

W optymalnym wariancie terapia powinna zawierać następujące elementy: całkowitą odpowiedź na neoadiuwantową ChRt/ChT, doszczętny onkologicznie zabieg resekcyjny typu R0. Zarówno ChRT/ChT, jak i radykalne leczenie chirurgiczne raka przełyku wiążą się jednak, w porównaniu z innymi nowotworami układu pokarmowego, ze stosunkowo wysokim ryzykiem powikłań i zgonów, niwelujących potencjalne korzyści z leczenia skojarzonego czy radykalizacji zabiegu chirurgicznego.

Uwzględniając powyższe dane, na czoło aktualnych intensywnych badań klinicznych wysuwają się próby identyfikacji tej grupy chorych, która odniesie potencjalnie największe korzyści z tak bardzo obciążającej terapii. Zakładając, że zgodnie z wytycznymi NCCN, ESMO standardem terapii miejscowo zaawansowanego raka przełyku w stopniach: T1b N+, T2-4a N0-N+ jest leczenie skojarzone w wariancie przedoperacyjnej ChRT z radykalnym wycięciem przełyku, możliwość przewidywania patologicznej odpowiedzi na neoadiuwantową ChRT stanowiłaby potencjalną korzyść dla wybranej grupy chorych na raka przełyku i mogłaby być ona kluczowym elementem postępu w leczeniu skojarzonym.

Jak do tej pory brak jest pewnej metody pozwalającej na prognostyczną identyfikację parametrów całkowitej odpowiedzi na stosowane leczenie skojarzone - ChRT lub ChT. Grupa badaczy z Heidelbergu, w oparciu o badanie MUNICON, zaproponowała monitorowanie zmniejszenia SUV (glucose standard uptake volume) w badaniu PET o > 35\% wartości wyjściowej w 14 . dniu od rozpoczęcia ChT jako metodę o wysokiej korelacji z histopatologiczną odpowiedzią na leczenie neoadiuwantowe [20]. Podobnie Heijl i wsp. z Rotterdamu, na podstawie randomizowanego badania EUROCON, od spadku SUV ponad 35\% w stosunku do wartości wyjściowej uzależniają kontynuację przedoperacyjnej ChRT [21].

W ostatnich latach daje się zauważyć duże zainteresowanie badaczy możliwością molekularnej identyfikacji markerów predykcyjnych pozytywnej odpowiedzi na chemio i/lub radioterapię. Czynione są próby, aby poprzez indywidualizację terapii odwrócić niekorzystny trend z 1 na 7-15 pacjentów reagujących na leczenie skojarzone do bardziej akceptowalnej proporcji, co powinno wpłynąć na poprawę skuteczności leczenia. Umożliwiłoby to również decyzję o przyśpieszeniu leczenia operacyjnego w przypadkach, gdy rak przełyku wykazuje oporność na leczenie onkologiczne [22, 23]. Dittrick i wsp. zwrócili uwagę, że takie podejście jest prognostycznie szczególnie ważne dla pacjentów, u których rejestruje się jedynie częściową odpowiedź patologiczną — pPR, stabilizację choroby — SD, czy wreszcie dalszą progresję choroby nowotworowej - PD [24]. W tych grupach pacjentów po ChRT i następowej operacji wyniki całkowitych przeżyć czy przeżyć wolnych od wznowy raka 
Tabela I. Udział raka płaskonabłonkowego przełyku w badaniach klinicznych z randomizacją nad skutecznością leczenia skojarzonego [14]

\begin{tabular}{|c|c|c|c|c|c|c|c|c|c|}
\hline \multirow{2}{*}{$\begin{array}{l}\text { Badanie } \\
\text { Maipang }\end{array}$} & \multirow{2}{*}{$\begin{array}{c}\text { Publikacja } \\
1994\end{array}$} & \multirow{2}{*}{$\begin{array}{c}\begin{array}{c}\text { Pacjenci } \\
\text { ogółem }\end{array} \\
46\end{array}$} & \multicolumn{2}{|c|}{$\begin{array}{c}\text { ESCC } \\
\mathrm{N} \%\end{array}$} & \multicolumn{2}{|c|}{$\begin{array}{c}\text { EACA } \\
\mathrm{N} \%\end{array}$} & \multicolumn{2}{|c|}{$\begin{array}{c}\text { EGJ ACA } \\
\text { N } \%\end{array}$} & \multirow{2}{*}{$\begin{array}{c}\text { Leczenie } \\
\mathrm{ChT}\end{array}$} \\
\hline & & & 46 & 100 & 0 & 0 & 0 & 0 & \\
\hline Law & 1997 & 147 & 147 & 100 & 0 & 0 & 0 & 0 & ChT \\
\hline Bosset & 1997 & 282 & 282 & 100 & 0 & 0 & 0 & 0 & ChRT \\
\hline Urba & 2001 & 100 & 25 & 25 & 75 & 75 & 0 & 0 & ChRT \\
\hline Boonstra & 2011 & 169 & 169 & 100 & 0 & 0 & 0 & 0 & ChRT \\
\hline Walsh & 1996 & 113 & 0 & 0 & 74 & 66 & 39 & 34 & ChRT \\
\hline Kelsen & 2007 & 443 & 207 & 47 & 236 & 53 & 0 & 0 & $\mathrm{ChT}$ \\
\hline Cao120 & 2009 & 473 & 473 & 100 & 0 & 0 & 0 & 0 & Rt, ChT, ChRT \\
\hline Ancona & 2001 & 94 & 94 & 100 & 0 & 0 & 0 & 0 & ChT \\
\hline Allum & 2009 & 802 & 247 & 31 & 451 & 56 & 82 & 10 & ChT \\
\hline Burmeister & 2005 & 256 & 95 & 37 & 158 & 62 & 0 & 0 & ChRT \\
\hline Ychou & 2011 & 224 & 0 & 0 & 25 & 11 & 144 & 64 & $\mathrm{ChT}$ \\
\hline Natsugoe & 2006 & 45 & 45 & 100 & 0 & 0 & 0 & 0 & ChRT \\
\hline Tepper & 2008 & 56 & 14 & 25 & 42 & 75 & 0 & 0 & ChRT \\
\hline Lv & 2010 & 238 & 238 & 100 & 0 & 0 & 0 & 0 & ChRT \\
\hline Lee & 2004 & 101 & 101 & 100 & 0 & 0 & 0 & 0 & ChRT \\
\hline Van Haggen & 2012 & 386 & 84 & 23 & 187 & 511 & 88 & 24 & ChRT \\
\hline \multirow[t]{2}{*}{ Razem } & & 3957 & 2267 & $57 \%$ & 1248 & $32 \%$ & 353 & $9 \%$ & ChT - 7; \\
\hline & & & & & & & & & ChRT -11 \\
\hline
\end{tabular}

są szczególnie niekorzystne, gorsze niż u poddanych jedynie operacji.

W celu opracowania optymalnego modelu strategii terapeutycznej w raku przełyku, ale też w nowotworach o innej lokalizacji prowadzone są badania markerów odpowiedzi na terapię skojarzoną w zakresie takich obszarów jak: badania mikromacierzy, badania polimorfizmów pojedynczych nukleotydów, mikro RNA, zmian epigenetycznych w procesach regulacji ekspresji genów, hamowania translacji, hamowania genów supresorowych i nieprawidłowej aktywacji onkogenów [22, 25]. Duże nadzieje wiąże się z badaniami w zakresie proteomiki, funkcjonalnej translacji genomu na białka efektorowe, $w$ dalszej kolejności z badaniami immunohistochemicznymi biomarkerów tkankowych, i wreszcie z badaniami markerów w surowicy krwi.

Okumura i wsp. przeanalizowali 17 publikacji pod kątem weryfikacji potencjalnych biomarkerów, które wstępnie są kwalifikowane jako przydatne w klinicznej odpowiedzi na przedoperacyjną ChRT, z możliwością w miarę wiarygodnego prognozowania wyników leczenia u chorych na raka płaskonabłonkowego [26]. W sumie autorzy zidentyfikowali 7 kategorii markerów molekularnych. Najlepiej zweryfikowaną grupą markerów są geny supresorowe (p53, p21). W następnej kolejności wymienia się geny regulatorowe cyklu komórkowego (cyklina D1, białka CD25B i 14-3-3 sigma), geny naprawy DNA (p53R2, geny pierwotnej naprawy DNA z grupy 1-ERCC1), białka odpowiedzialne za oporność na leki (metallothioneina), czynniki angiogenne (VEGF), geny proliferacji komórkowych, inwazji i przerzutowania (COX-2, Ki-67) oraz geny regulatorowe szlaku sygnalizacji międzykomórkowych (Hedgehog) na etapie morfogenezy i stymulacji komórek macierzystych do różnicowania (Gli-1).

Findlay i wsp. z Oksfordu, na podstawie przeglądu 762 artykułów, do ostatecznej weryfikacji włączyli 182 publikacji, w tym 92 metaanalizy, w oparciu o które udało im się wyselekcjonować aż 65 potencjalnych markerów biologicznych odpowiedzi raka przełyku na ChT [27]. Większość publikacji była jednak wg autorów metodologicznie heterogenna, ze znacznym utrudnieniem jednoznacznych wniosków.

W celu określenia realnej wartości poszczególnych markerów niezbędny jest kolejny etap intensywnych badań walidacyjnych. Najlepiej, gdyby miały one charakter metaanaliz wieloośrodkowych badań z randomizacją (mcRCT). Tylko w tym zakresie - analizy wzajemnych korelacji jedynie 65 potencjalnych markerów, liczba możliwych kombinacji równa 65(!) jest niewyobrażalnie wysoka; 824 i 89 zer, co w jednoznaczny sposób determinuje niską wartość predykcyjną praktycznie wszystkich dotychczasowych badań i publikacji w tym zakresie. Znany od 2007 roku kompletny skład genomu ludzkiego na poziomie 34000 genów, a także 0,5-1 milion białek ustrojowych oraz fakt, że jakikolwiek efekt biologiczny jest dodatkowo korelowany przez ok. 200 białek ustrojowych, uzmysławia nam skalę możliwych kombinacji i wzajemnych korelacji markerów oraz pokazuje problemy i wyzwania, przed jakimi stoimy. To w jakimś sen- 
sie determinuje również nasze możliwości w kształtowaniu strategii terapii raka przełyku i nowotworów w ogóle.

Na pytanie zadane przez Organizatorów III edycji Debat Onkologicznych w 2015 roku, czy w operacyjnym raku przełyku należy stosować neoadiuwantową/indukcyjną ChRT, a następnie operować pacjenta - w pierwszym odruchu, oraz opierając się na danych z literatury, własnym i krajowym doświadczeniu klinicznym oraz na rozumieniu współczesnych zasad uprawiania medycyny w oparciu o poprawnie metodologicznie i obiektywnie potwierdzone statystycznie metaanalizy prospektywnych, wielośrodkowych badań klinicznych z randomizacją — odpowiedziałem „tak" [28].

Jednak uwzględniając powyższe informacje i krytycznie analizując rzeczywiste korzyści dla konkretnego pacjenta, mimo istotnego postępu wiedzy i możliwości terapeutycznych — realnie tylko jeden na 7-15 pacjentów odnosi korzyści z zastosowania przedoperacyjnej ChRT. To z kolei zmusza mnie do wyrażenia dużych wątpliwości odnośnie tego, jak powinienem odpowiedzieć na zadane pytanie. Mój sceptycyzm w jakimś sensie potęguje również świadomość jakości publikacji i niestety ułomności metodologicznej zdecydowanej większości prowadzonych badań klinicznych w zakresie onkologii klinicznej czy chirurgicznego leczenia nowotworów.

Teoretycznie powszechnie akceptowane są zasady prowadzenia badań klinicznych i zalecenia metodologiczne odnośnie poziomów ewidencji i stopni rekomendacji, opracowane przez Americal College of Chest Physicians [29]. Jednak wg szczegółowych danych z bazy MEDLINE opublikowanych przez Abbrozzese'a i wsp. na ponad 11 mln wszystkich artykułów na temat litych guzów nowotworowych tylko 0,03\% miało charakter badań prospektywnych z randomizacją pRCT [30]. Jeśli nawet przyjąć tezę, że w ciągu 10-15 lat zanotowano istotną poprawę jakości badań klinicznych, to i tak badania pRCT/metaanalizy nadal stanowią niewielki odsetek publikowanych artykułów. W okresie ostatniego 20-lecia szczegółowa analiza jakości publikacji odnośnie guzów litych jest nieco lepsza. Wg autorów kryteria poziomu ewidencji la spełniało dla guzów litych tylko 6,7\% publikacji, natomiast dla nowotworów przełyku jedynie 5,97\% (tab. II).

Co więcej, w odniesieniu do najbardziej aktualnych wytycznych, zaleceń wielu towarzystw i organizacji zajmujących się terapią nowotworów, moje krytyczne podejście do zasadności obligatoryjnego stosowania leczenia skojarzonego ChRT w raku przełyku, a także do korzyści odnoszonych przez chorych na raka przełyku jest potęgowane po przejrzeniu poziomu ewidencji i stopnia rekomendacji poszczególnych zaleceń diagnostyczno-terapeutycznych w ogóle, a dla chorych na raka przełyku w szczególności. Większość zaleceń brytyjskich (około 50\%) jest w stopniu rekomendacji B, poniżej $20 \%$ w stopniu A i blisko $30 \%$ w stopniu C. Z kolei podstawowy poziom ewidencji zaleceń amerykańskich w zakresie terapii raka przełyku to lla [31-33].
Tabela II. Analiza publikacji wg poziomu ewidencji la wg zasad EBM

\begin{tabular}{lcc}
\hline Lokalizacja guza & MEDLINE & Publikacje la wg EBM (\%) \\
\hline Głowa i szyja & 39 & 7 \\
Przełyk & 184 & $11(5,9)$ \\
Żołądek & 121 & 14 \\
Trzustka & 129 & 6 \\
Jelito grube & 528 & 21 \\
Mięsaki & 32 & 7 \\
Czerniak & 295 & 22 \\
Sutek & 338 & 22 \\
Szyjka macicy & 48 & 7 \\
Trzon macicy & 25 & 1 \\
Wątroba & 170 & 6 \\
Drogi żółciowe & 40 & 1 \\
Jelito cienkie & 11 & 2 \\
Odbyt & 7 & 3 \\
Razem & 1967 & $130(6,7)$ \\
\hline
\end{tabular}

W odniesieniu do możliwości prowadzenia poprawnych metodologicznie badań klinicznych w chirurgii onkologicznej, będących podstawą skojarzonego leczenia guzów litych, w tym raka przełyku, aż 56\% badań RCTs było źle zaplanowanych [31]. Jedynie 58\% miało właściwy dobór metod randomizacji, tylko w kilku uzyskano istotne statystycznie różnice, najprawdopodobniej z powodu tzw. Il typu błędu statystycznego. Jednocześnie dokładna analiza tych publikacji pod kątem spełnienia kryteriów EBM wykazała, że tylko 40\%-60\% problemów w chirurgii onkologicznej da się rozwiązać poprzez prospektywne badania RCT.

Problemów w tym zakresie jest kilka. Przede wszystkim chodzi o prawidłowe, krytyczne sformułowanie pytania, odpowiednie zaplanowanie badania i określenie mocy dowodów. Do opracowania konstruktywnych, wiarygodnych zaleceń wymagane jest systematyczne pozyskiwanie najlepszych dostępnych dowodów naukowych, krytyczna ocena ich spójności wewnętrznej, a także uwzględnienie określonych parametrów statystycznych, które pozwolą na obiektywne i wiarygodne wnioski kliniczne [34].

Szczegółowe analizy są wysoce niepokojące i wskazują na niedoskonałość metodologiczną publikacji z badań klinicznych w chirurgii, w tym również w zakresie chirurgii onkologicznej. Podważa to ich wartość jako dowodów naukowych, stanowiących podstawę między innymi zaleceń odnośnie skojarzonego leczenia raka przełyku [35, 36]. Hall i wsp., na podstawie przeglądu 364 badań z randomizacja z 10 wiodących czasopism chirurgicznych, udowodnili, że ich jakość, a w związku z tym i wiarygodność wyników mogą być kwestionowane. Główne błędy dotyczyły metod randomizacji — jedynie $27 \%$ było poprawnych metodologicznie, kalkulacji wielkości badanej próby (19\%), niezakłóconej oceny wyników (48\%) i definicji punktów końcowych (65\%). 
Guller zwraca również uwagę na konieczność właściwego wyboru hipotezy badawczej — hipotezy zerowej lub alternatywnej jedno/dwustronnej oraz wielkości próby, aby zminimalizować prawdopodobieństwo wyników pozytywnie i negatywnie fałszywych, tzw. błędów I ill typu [37]. Problem ten jest szczególnie istotny przy próbach optymalizacji skojarzonego leczenia raka przełyku. Hipoteza, że np. nowy schemat ChT/ChRT w miejscowym zaawansowaniu raka przełyku podnosi wskaźnik przeżycia, powinna uwzględniać fakt, że pacjenci mogą umierać wcześniej z powodu nieoczekiwanych, ciężkich objawów niepożądanych.

Całość problemu wiarygodności badań klinicznych w chirurgii doskonale podsumował Horton w swoim artykule zatytułowanym „Surgical research or comic opera: Questions but few answers", co w jakimś sensie może oddawać ducha również mojej opinii odnośnie pytania Organizatorów III Debat Onkologicznych [38].

\section{Prof. dr hab. n. med. Grzegorz Wallner}

II Katedra i Klinika Chirurgii Ogólnej, Gastroenterologicznej i Nowotworów Układu Pokarmowego, Uniwersytet Medyczny w Lublinie

ul. Staszica 16, 20-081 Lublin

e-mail:gt_wallner@interia.pl

\section{Otrzymano i przyjęto do druku: 9 lutego $2016 \mathrm{r}$.}

Na podstawie wystąpienia podczas III Konferencji Naukowej czasopisma Nowotwory „Debaty onkologiczne”, 10-11 kwietnia 2015 roku.

\section{Piśmiennictwo}

1. Urschel JD i wsp. A meta-analysis of RCTs that compared neoadjuvant chemoradiation and surgery to surgery alone for resectable esophageal cancer. Am J Surg 2003; 185: 538-543.

2. Greer SE i wsp. Neoadjuvant chemoradiotherapy for esophageal carcinoma: a meta-analysis. Surgery 2005; 137: 172-177.

3. Jin H-L i wsp. Neoadjuvant chemorediotherapy for resectable esophageal carcinoma: a meta-analysis. World J Gastroenterol 2007; 15 : 5983-5991.

4. Mariette $\mathrm{Ch}$ i wsp. Therapeutic strategies in oesophageal cancer: a role of surgery and other modalities. Lancet Oncol 2007; 8: 545-553.

5. GebskiV i wsp. Survival benefits from neoadjuvant chemoradiotherapy of chemotherapy in oesophageal carcinoma: a meta-analysis. Lancet Oncol 2007; 8: 226-234

6. Lordick F i wsp. PET to assess early metabolic response and to guide treatment of adenoca of the EGJ: the MUNICON phase II trial. Lancet Oncol 2007; 8: 797-805.

7. Kranzfelder M, Büchler P i wsp. Treatment options for squamous cell cancer of the esophagus: A systematic review of the literature. J Am Coll Surg 2010; 210: 351-359.

8. Zemanova M i wsp. Prospective non-randomized study of preoperative concurrent platinum plus 5 Fu-based CRT with or without paclitaxel in esophageal cancer pts: long-term follow-up. Dis Esoph 2010; 23: 160-167.

9. Courrech Staal EFW, van Sandick JW i wsp. Systemic review of the benefits and risks of neoadjuvant chemoradiation for oesophageal cancer. Br J Surg 2010; 97: 1482-1496.

10. Crehange G i wsp. Preoperative radiochemotherapy for resectable localised oesophageal cancer. A controversial strategy. Clin Rev Oncol Hematol 2010; 71: 235-242.

11. Walsh Th. Oesophageal cancer: who needs neoadjuvant therapy? Lancet Oncol 2011; 12:615-616 neoadjuvant CRT in pts with potentially curable esophageal cancer. Ann Surg 2011; 253: 56-63.

12. Ronellenfitsch $\mathrm{U}$ i wsp. Preoperative $\mathrm{C}(\mathrm{R})$ therapy vs primary surgery for gastroesophageal adenocarcinoma: systematic review with meta-analysis combining individual patient and aggregate data. Eur J Cancer 2013; 49: 3149-3158.

13. D'Journo X-B i wsp. Current management of esophageal cancer. JThorac Dis 2014; 6: S253-S264.

14. Skoczylas T.Znaczenie przedoperacyjnejchemioterapii ichemioradioterapii w leczeniu skojarzonym płaskonabłonkowego raka przełyku. Rozprawa habilitacyjna. Uniwersytet Medyczny w Lublinie, Lublin 2013.

15. Burnmeister BH i wsp. Surgery alone vs chemoradiotherapy followed by surgery for resectable cancer of the esophagus: a randomised controlled phase III trail. Lancet Oncol 2005; 6: 659-668.

16. Sjoquist KM, Gebski V for the Australasian Gastro-Intestinal Trials Group. Survival after neoadjuvant ChT or ChRT for resectable oesophageal carcinoma: an updated meta-analysis. Lancet Oncol 2011; 12: 681$-692$

17. Kranzfelder M, Schuster T, Geinitz Hi wsp. Meta-analysis of neoadjuvant treatment modalities and definitive non-surgical therapy for oesophageal squamous cell cancer. Br J Surg 2011; 98: 768-783.

18. Ronellenfitsch U i wsp. GE Adenocarcinoma Meta-analysis Group. Perioperative chemo(radio)therapy versus primary surgery for resectable adenocarcinoma of the stomach, gastroesophageal junction, and lower esophagus. Cochrane Database Syst Rev 2013 May 31; 5: CD008107.

19. Ronellenfitsch U i wsp. Preoperative chemo(radio)therapy versus primary surgery for gastroesophageal adenocarcinoma: systematic review with meta-analysis combining individual patient and aggregate data. Eur J Cancer 2013; 49: 3149-3158.

20. Lordick F i wsp. PET to assess early metabolic response and to guide treatment of adenoca of the EGJ: the MUNICON phase II trial. Lancet Oncol 2007; 8: 797-805

21. van Heijl M i wsp. Fluorodeoxyglucose Positron Emission Tomography for Evaluating Early Response During Neoadjuvant Chemoradiotherapy in Patients With Potentially Curable Esophageal Cancer. Ann Surg 2011; 253: 56-63.

22. Uemura N, Kondo T. Current status of predictive biomarkers for neoadjuvant therapy in esophageal cancer. World J Gastrointest Pathophysiol 2014; 5: 322-334.

23. Baba $\mathrm{Y}$, Watanabe $\mathrm{M}$ i wsp. Neoadjuvant treatment for esophageal squamous cell carcinoma. World J Gastrointest Oncol 2014; 6: 121-128.

24. Dittrick GW i wsp. Pathologic nonresponders after neoadjuvant CRT for esophageal cancer demonstrate no survical benefit compared with pts treated with primary esophagectomy. Ann Surg Oncol 2012; 19: 1678-1684.

25. Kaz AM, Grady WM. Epigenetic biomarkers in esophageal cancer. Cancer Letters 2014; 342: 193-199.

26. Okumura $\mathrm{H}$ i wsp. Biomarkers for predicting the response of esophageal squamous cell carcinoma to neoadjuvant chemoradiation therapy. Surg Today $2014 ; 44: 421-428$.

27. Findlay JM, Middleton MR, Tomlinson I. A systematic review and meta-analysis of somatic and germline DNA sequence biomarkers of esophageal cancer survival, therapy response and stage. Ann Oncol 2015; 26: 624-644.

28. Skoczylas T. Rozprawa habilitacyjna, Lublin 2013.

29. Guyatt G, Gutterman D, Baumann M i wsp. Grading strength of recommendations and quality of evidence in clinical guidelines: report from an American College of Chest Physicians task force. Chest 2006; 129: 174-181.

30. Abbrozzese JM i wsp. The search for level I evidence in solid tumor oncology Ann Surg Oncol 2001; 8: 638-645.

31. McCulloch P i wsp. Randomised trials in surgery: problems and possible solutions. BMJ 2002; 324: 1448.

32. Grenda TR. The role of surgery in the management of regionally advanced esophageal squamous cell carcinoma. (w Ferguson MK (red.). Difficult Decisions in Thoracic Surgery: An Evidence-Based Approach) 2014; 24: 298-310.

33. Esophageal and Esophagogastric Junction Cancers. NCCN Clinical Practice Guidelines in Oncology 2015; ver.2.2015.

34. Norton J, Barie P, Bollinger R i wsp. (red.). Surgery: Basic Science and Clinical Evidence. Springer Science \& Business Media, 2009.

35. Hall JC i wsp. Methodological standards in clinical trials. Surgery 1996; 119: 466-472.

36. Hall JC i wsp. Randomized controlled trials in surgery. Surgery 1994; 115: 707-712.

37. Guller U. Sample size matters: a guide for surgeons. World J Surg 2005; 29: 601-605.

38. Horton R. Surgical research or comic opera: questions, but few answers. Lancet 1996; 347: 984-985. 